\title{
AMONG BIRDS AND NET(WORK)S: MATERIAL AND SOCIAL PRACTICES IN THE TRAJECTORY OF ORNithologist EMILIE SNETHLAGE $(1868-1929)$
}

\author{
Miriam Junghans \\ Doctoral candidate at Casa de Oswaldo Cruz/Fiocruz \\ Rio de Janeiro \\ miriamjung@gmail.com
}

\begin{abstract}
In the course of her career, German ornithologist Emilie Snethlage (1868-1929), who worked in Brazil in the early twentieth century, was involved in all the steps that characterize the "production" of a specimen for scientific collection: from fieldwork, with the collection and preparation of materials, to their description and publication of results. Each of these stages mobilizes different material practices and sociability networks. During fieldwork or in her museum activities, the fact of being a woman demanded from Snethlage specific strategies for establishing her scientific legitimacy, analyzed in this article, especially her activities related to collecting practices.
\end{abstract}

Keywords: Women scientists, Ornithology, Scientific collections, Germany, Brazil

\section{Introduction}

Grallaria martinsi, Synallaxis martinsi, Picumnus limae and Xiphocolaptes promeropirhynchus berlepschi are birds found in the northern region of Brazil. They were collected, described, identified, and named by German

HoST - History of Science and Technology 10, pp. 71-101 DOI $10.1515 /$ host-2016-0004 
ornithologist Emilie Snethlage (1868-1929), who worked in the country between 1905 and 1929. In spite of its apparent coldness, the scientific nomenclature allows for a glimpse, in the above cases, into human interactions, relationships, and contact networks, since Snethlage named these birds in honour of her co-workers. The species name martinsi refers to Oscar Rodrigues Martins (18?-18/19?), an assistant helper at the Zoological Section of the Goeldi Museum, in which Snethlage worked 11 The species name limae refers to Francisco de Queiroz Lima (18?-18/19?), an assistant to whom, according to Snethlage, museum collections "owe many of its treasures." $\mathrm{I}^{2} \mathrm{Un}$ fortunately, we have no further information regarding those accompanying the ornithologist on her trips and helping her to capture and to prepare the birds that would become part of the museum collections. The species name berlepschi, in turn, is a reference to the German ornithologist and collector Count Hans von Berlepsch (1850-1915), a specialist in South American ornithology to whom Snethlage often resorted for help in identifying the collected specimens ${ }^{3}$ Two Brazilian museum assistants and a German aristocrat, therefore, provide a small glimpse into Snethlage's scientific social networks, the named birds hinting at the great social and physical distance among its participants. However, one characteristic in the network stands out: it was a predominantly a male world as few women worked in professional ornithology in the early twentiethcentury; Emilie Snethlage was one of them.

Acceptance and recognition of the work developed by a scientist is a process that involves several variables of a social nature. For analytical purposes it is possible to focus on specific aspects of the scientific work, as this paper does, which examines some of the instances involved in the construction process of Emilie Snethlage's scientific legitimacy ${ }^{4}$ The theoretical approach builds on Jardine and Spary $!_{5}^{5}$ for whom the field of natural history may be

\footnotetext{
${ }^{1}$ Nelson Sanjad, A coruja de Minerva: o Museu Paraense entre o Império e a República (1866-1907) (Brasília: Instituto Brasileiro de Museus; Belém: Museu Paraense Emílio Goeldi; Rio de Janeiro: Fundação Oswaldo Cruz, 2010), 216, 220.

${ }^{2}$ Emilie Snethlage, "Novas espécies de aves do N.E. do Brasil," Boletim do Museu Nacional 1 (1925): 410.

3 The mention of Xiphocolaptes promeropirhynchus berlepschi can be found in Emilie Snethlage, "Sobre uma coleção de aves do Rio Purús," Boletim do Museu Paraense de História Natural e Ethnographia, 5 (1907-1908): 43.

${ }^{4}$ See Miriam Junghans, "Avis rara: a trajetória da naturalista alemã Emilie Snethlage (1868-1929) no Brasil" (MA diss., Casa de Oswaldo Cruz/Fiocruz, Rio de Janeiro, 2009). I am grateful to Paulo Scarpa for the translation.

${ }^{5}$ Nicholas Jardine and Emma Spary, "The natures of cultural history," in Cultures of Natural History ed. Nicholas Jardine, James Secord and Emma Spary (Cambridge: Cambridge University Press, 1997), 8.
} 
understood as "the product of conglomerates of people, natural objects, institutions, collections, finances, all linked by a range of practices of different kinds." These practices interest us here, especially the material, social, and bodily practices. According to those authors, social practices are ways to recruit scientists, associations and negotiations, as well as sociability networks in general, involving the relationship between the scientist and her peers, or between the scientist and her assistants and superiors, and between the scientist and the various social environments she has attended. These practices also include the various institutions attended by the naturalist during her professional training and activities. The material practices include forms of obtaining, transporting, handling, and transforming natural history objects, which, in the case of Snethlage generally refers to ornithological specimens. Lastly, bodily practices comprise presentations, attire, bodily and gestural arrangements, and behavioural norms; in Snethlage's case, this comprised especial attention to her physical appearance and clothing. Jardine and Spary's proposal for understanding different types of practices as different sides of a same culture combines into a single process aspects commonly presented separately, such as social and material practices. This is particularly important when analysing scientific collection activities as it allows us to combine abstract aspects, such as scientific social networks, with more concrete dimensions, such as a scientist's attire or the transformations that take place in objects intended for scientific study.

Among the analysed documental sources, we have letters written by the scientist to her family, some of her published articles, the obituary written by her nephew, institutional archive documents, period publications that reference her, in addition to secondary sources.

\section{Networks}

Emilie Snethlage arrived at the port of Belém do Pará, Brazil, on August 15, 1905. At 37, she was among the first women to earn a doctorate in Germany. She had obtained her title just a year before, in 1904 at the University of Freiburg im Breisgau, after studying in Berlin and Jena. She began her professional life as an ornithologist at the Museum für Naturkunde in Berlin in 1905 and in the same year, at the invitation of the Swiss zoologist Emilio Goeldi (1859-1917), she went to work in the Goeldi Museum in Belém. ${ }^{6}$ Thus began her prolific career in Brazilian lands, which led her to

\footnotetext{
${ }^{6}$ The Museu Paraense de História Natural e Etnografia was renamed in honor of Emilio Goeldi in 1900 and in 1931 received its current name, Museu Paraense Emílio Goeldi
} 
explore, until her death in 1929, much of the country's territory at service of Museu do Pará and later of the National Museum in Rio de Janeiro. For 24 years, she worked the whole scope of scientific activity: she dedicated herself intensely to field work, published several articles and an important ornithological catalogue, and took on administrative tasks, including the direction of the Goeldi Museum. The importance of her work is recognized by scientists and intellectuals in Brazil and abroad 7 and the specimens she collected are part of important ornithological collections in Brazilian and foreign institutions (figures 1).

The woman who arrived in Belém do Pará in 1905 brought considerable symbolic capital with her as she had been trained by leading European scientists, and the first plots of a scientific sociability network that would soon gain new contacts established from her work at the museum. Her path from Berlin to Belém had been far from conventional. A scientific background in the early twentiethcentury was not a social status shared by many women, and Emilie Snethlage's path was the result of many social contingencies and personal decisions until she fully came to practice a scientific profession, as we shall see.

Emilie Snethlage was born in Prussia in April 13, 1868, in the village of Kraatz (north of Berlin), currently belonging to the city of Gransee. Emilie's mother died when she was four years old and her father, a Lutheran minister, home schooled Emilie and her brother since there were no schools close to Kraatz 8 The Protestant clergy had access to an extensive education, which included knowledge of the natural world and one can imagine that Snethlage's initial education by her father was different from the education destined to other girls. Through her nephew's account, Emil Heinrich

\section{(MPEG).}

${ }^{7}$ She is mentioned - always with admiration - by Theodore Roosevelt in Through the Brazilian Wilderness (London: John Murray, 1914) and in correspondence between ornithologists Charles Hellmayr and Erwin Stresemann (in Jürgen Haffer, "OrnithologenBriefe des 20. Jahrhunderts," Ökologie der Vögel 19 (1997). In the Brazilian context, her importance is recognized, among others, by anthropologist Edgar Roquette-Pinto his essay entitled "Snethlage: alma de mulher e de sabia," in Ensaios brasilianos (São Paulo: Companhia Editora Nacional, 1940), 88-90 and by ornithologist Helmut Sick, who dedicated his major work to her, Ornitologia brasileira (Rio de Janeiro: Nova Fronteira, 1997), originally published in 1985. Snethlage is also a character in a novel by regional author Raimundo de Morais, Os igaraúnas (São Paulo: Roswitha Kempf, 1985), 1938. In this work, she is referred to as "the German from the Museum" who "knows of everything," 67.

${ }^{8}$ Nelson Sanjad et al, "Emília Snethlage (1868-1929): um inédito relato de viagem ao rio Tocantins e o obituário de Emil-Heinrich Snethlage," Boletim do Museu Paraense Emílio Goeldi. Ciências Humanas, 8, (2013): 195-221, on p. 212, note 52. 


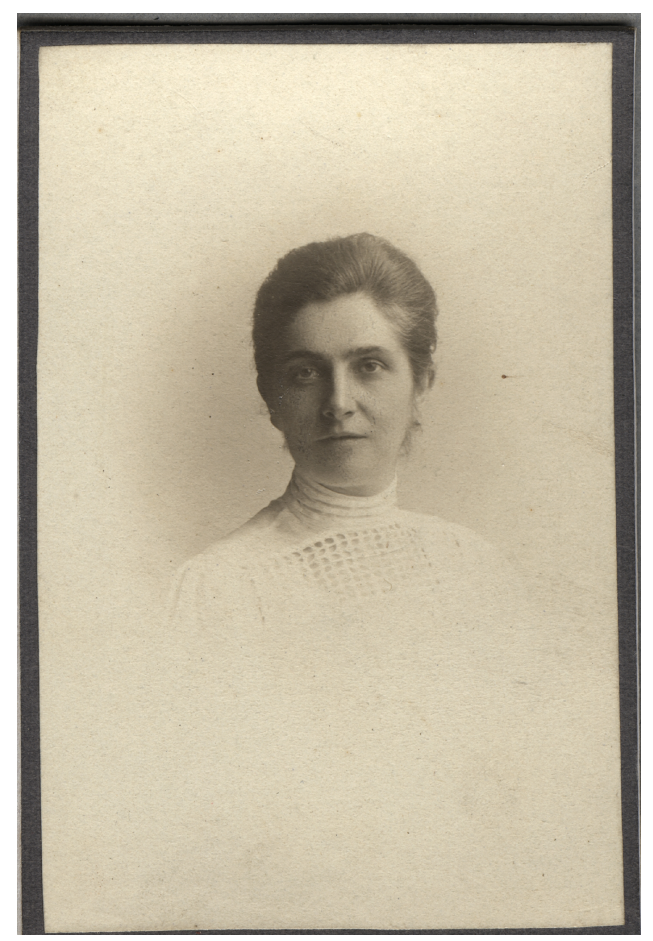

Figure 1: Emilie Snethlage portrait, 1906 (Museum für Naturkunde Berlin/Historische Bild- und Schriftgutsammlungen)

Snethlage, an ornithologist and ethnographer 9 , we know that Emilie Snethlage had contact with amateur natural history collecting, which was common in Europe at the time 10 The girl was encouraged to organize a herbarium,

\footnotetext{
${ }^{9}$ Emil-Heinrich Snethlage (1897-1939) studied botany and zoology at the universities of Freiburg, Kiel, and Berlin, where he graduated in 1923 with a work on ornithology. In the same year, he arrived in Brazil and travelled across the state of Maranhão along with his aunt. Between 1924 and 1926, he worked for the Field Museum of Natural History in Chicago as an ornithologist, traveling the states of Maranhão, Piauí and Ceará. These trips awakened in him an interest in ethnography, leading to a change in his professional field. The Berlin Museum of Ethnography contracted him in 1927 as a curator. Between 1933 and 1935, sponsored by the Arthur Baessler Foundation, he traveled along the Guaporé River, on the border between Brazil and Bolivia. Once he returned to Europe, he published various articles on ethnography, archaeology, and ethnomusicology, as well as a popularization book (Atiko y). World War II interrupted his career in 1939. For more on Emil Snethlage, see Gleice Mere, "Emil-Heinrich Snethlage (1897-1939): nota biográfica, expedições e legado de uma carreira interrompida," Boletim do Museu Paraense Emílio Goeldi. Ciências Humanas 8 (2013): 773-804.

${ }^{10}$ David Allen studied Britain's amateur traditions in natural history in his seminal
} 
for which she collected "four plants every day," to read the works of Hermann Wagner, a popular natural history author at the time, and had sent comments on birds to ornithologist Rudolf Blasius (1842-1907) ${ }^{11}$, which were published in the Journal für Ornithologie ${ }^{12}$ Knowledge of the natural world, therefore, was part of Snethlage's initial education, and one can imagine the existence of some kind of bond between her family and the academic world of ornithology. However, in the second half of the nineteenth century, a scientific career would hardly be among the professional options of the daughter of a village pastor.

In 1889, Snethlage took the official exam to allow her to teach in secondary school for young women and concluded her training as an educator spending a year in Neuchâtel, Switzerland, a former Prussian principality, where she perfected her knowledge of French. For the following ten years, she worked as a tutor for children for families in England, Ireland, and Germany. Still according to her nephew, due to a small inheritance she received, Snethlage was able to enrol at the University of Berlin in 1900 to "fulfil her childhood dream," the study of natural history ${ }^{13}$ With this new moment in her professional life, Snethlage studied in Berlin, Jena, and Freiburg im Breisgau, where she earned her doctorate with a thesis, illustrated by herself, on the origin and insertion of the muscles of arthropods 14 The study consisted of research on comparative morphology at the cellular level and ontogenetic research, which characterizes Snethlage's participation in biological studies, particularly morphology, then being conducted at German universities. Her doctoral work came during an extremely prolific moment in the field we would currently call the life sciences, during the passage from the nineteenth to the twentiethcentury. Darwin's influence in understanding natural processes, from the publication of The Origin of Species in 1859,

work The naturalist in Britain: a social history (Princeton: Princeton University Press, 1976). For Europe in general, see Jean-Marc Drouin and Bernadette Bensaude-Vincent, "Nature for the people," in Jardine, Secord and Spary eds., Cultures of Natural History, 408-425.

${ }^{11}$ Rudolf Blasius, born into a family of renowned ornithologists, occupied prominent scientific positions such as the presidency of the German Society of Ornithologists (Deutsche Ornithologen-Gesellschaft, DO-G), whose official publication was the Journal für Ornithologie. The publication was founded in 1853, currently called Journal of Ornithology, and is considered the oldest journal of the field still in publication.

${ }^{12}$ Emil-Heinrich Snethlage, "Dr. Emilie Snethlage zum Gedächtnis," Journal für Ornithologie, 78 (1930): 123-134, on p. 123.

${ }^{13}$ E.-H. Snethlage, "Dr. Emilie Snethlage zum Gedächtnis," 123.

${ }^{14}$ Emilie Snethlage, "Über die Frage vom Muskelansatz und der Herkunft der Muskulatur bei den Arthropoden" (Inaugural diss., Universität Freiburg i.B., 1905 published as an offprint of the Zoologischen Jahrbüchern, 21 (1905).

HoST - History of Science and Technology 10, pp. 71-101 DOI $10.1515 /$ host-2016-0004 
was deeply felt in Germanic culture. Darwinism's reception was not without resistance, but in the newly unified Germany (1871), Darwin's thought was well accepted in some academic fields.

We shall see how in her passage through German universities, Snethlage acquired, in addition to knowledge, her respectable symbolic capital. Her thesis advisor, for example, was August Weismann (1834-1914), recognized as one of the most important names in evolution theory after Darwin. In a time when zoology was conquering its space as an independent discipline, separating itself from the medicine, Weismann earned the first chair of the new discipline in Germany. He taught at Freiburg i.B. between 1863 and 1912. During her stay in Jena, Snethlage had contact with another Darwinism proponent in Germany, Ernst Haeckel (1834-1919), of whom she became a student 15 Haeckel had translated Darwin into German and taught comparative anatomy and zoology at Jena for almost fifty years, from 1862 to 1909, turning his university into a Darwinism dissemination center. Haeckel's best-known contribution to the study of evolutionary processes was the embryonic recapitulation theory, later refuted 16

However, Snethlage's entry into the academic world, hitherto exclusively male, was not without difficulties. Her thesis was qualified as summa cum laude, a testament of her extreme dedication and competence within a rigid organization in which renowned full professors monopolized chairs for decades. Women attending university courses in German culture between the late nineteenth and early twentiethcentury shared the challenges faced by Snethlage. Change in universities - which began to officially accept the enrolment of women in their courses during this period-began mostly due to pressure from women's rights movements and the support they garnered from some society sectors. Up until then, women were allowed to attend classes as listeners in some exceptions, and some even graduated. The first German-speaking country to accept women into university was Switzerland, in 1865, followed by Austria, which had since 1878 allowed women to attend classes as listeners. In Germany, the University of Freiburg i.B. was the first to accept the enrolment of women starting from the 1899/1900 semester. The first women earned PhD degrees in Freiburg in 1901 and in Jena in 1904. In Berlin, women would only be officially accepted in $1908{ }^{17}$ When

15 Alípio de Miranda-Ribeiro, "Discurso de recepção da Dra. Emília Snethlage na Academia Brasileira de Sciencias e em nome desta proferido em sessão de 26 de outubro de 1926," Boletim do Museu Nacional, 12 (1936): 77-85, on p. 81.

${ }^{16}$ For more on Haeckel see Guilherme Francisco Santos, A teoria da gastrea de Ernst Haeckel, (MA diss., São Paulo University, 2011).

${ }^{17}$ Miriam Junghans, "Emília Snethlage (1868-1929): uma naturalista alemã na 
Snethlage attended the University of Berlin in 1900, her situation was exceptional regarding the conditions under which she was allowed to attend classes, as is clear in Emilie's great-nephew Rotger Snethlage's account: "the student should arrive to the auditorium fifteen minutes prior to the start of the lecture, and must remain behind a folding screen. She was not allowed to express herself in anyway whatsoever during class and should leave the premises only after the passage of fifteen minutes since the end of the presentation." 18 The need to "remain behind a folding screen," however, seems to have favoured Snethlage's concentration and learning, and she successfully defended her doctoral thesis on 12 July, 1904.

After completing her university studies, Snethlage returned to Berlin, where she worked for six months as a zoology assistant at the Museum für Naturkunde, under the orders of the German ornithologist Anton Reichenow (1847-1941) ${ }^{19}$ Berlin's Museum für Naturkunde was a centre congregating scientific material collected from several parts of the world, especially from the German colonial rule areas, a model Sheets-Pyenson called the "Metropolitan Museum." 20 The institution originated from the merger of three museums belonging to the University of Berlin ${ }^{21}$ the Comparative Anatomy Museum (Anatomisch-Zootomische Museum), the Zoology Museum and the Mineralogical Museum. The growth of the collections in these museums throughout the nineteenth century made it impossible for them to remain in university facilities. Therefore, in 1889, the Invalidenstrasse 43 building opened, which enabled the internal organization of the collections to be divided-according to a paradigm recently introduced in the "world of museums"-among research and display collections.

Reichenow, who started at the museum as an assistant in 1874 and assumed the management of the institution as a substitute in 1906, was integrated into networks interconnecting professionals in German ornithology

Amazônia," História, Ciências, Saúde - Manguinhos 15, (2008): 243- 255, on p. 245, note 3 .

${ }^{18}$ Rotger Snethlage in an interview with Brazilian journalist and photographer Gleice Mere, who I kindly thank for sending me the material and authorizing its use.

${ }^{19}$ In addition to being an ornithologist, Reichenow was a herpetologist. His preferred field of study, however, was birds, especially those from the African continent, which he had the opportunity to research during an expedition between 1872 and 1873 to the German colonial region in West Africa (currently comprising Togo, Cameroon, and Namibia).

${ }^{20}$ Susan Sheets-Pyenson, Cathedrals of science: the development of colonial natural history museums during the late nineteenth century (Kingstom: McGill/Queen's University Press, 1988).

${ }^{21}$ Currently Humboldt-Universität zu Berlin, founded in 1810 by linguist and educator Wilhelm von Humboldt (1767-1835), emphasizing the combination of research and teaching. 
by family and work ties, and would become an important contact in Snethlage's network. Besides being editor-in-chief of the Journal für Ornithologie between 1893 and 1921, he was also editor of the Ornithologischen Monatsberichte. These two journals would come to publish 21 of Snethlage's articles. It was through Reichenow that Snethlage knew of a job opening for a zoology professional in a museum in South America, the Goeldi Museum in Belém do Pará.

Museu do Pará was under the direction of Emílio Goeldi and his contact with Reichenow serves as an example of the "workings" of scientific sociability networks. Born in Bern, Switzerland, Goeldi began his scientific career in 1881 at the Zoological Station in Naples, a marine biology research centre founded by German zoologist Anton Dohrn (1840-1909). He later studied at the universities of Leipzig and Jena, where he was a student of Haeckel, as Snethlage would be a few years later, and defended his thesis in 188422 Goeldi moved to Brazil soon after graduating, working initially for the National Museum in Rio de Janeiro for five years. The move to Pará occurred in 1894, by the invitation of the state governor, the positivist Lauro Sodré (1858-1944). The North of Brazil, especially Pará, by channelling all of the region's production, saw in the late nineteenth and early twentieth century a period of economic growth derived from rubber extraction, the demand and prices of which were on the rise in the world market. The capital received major investments in education, infrastructure, and urban improvements. Part of these investments went to the restructuring of a natural history museum founded in 1866 in Belém, of which only a part of the collection remained. Emilio Goeldi moved to Belém with the mission of organizing the museum. The reorganization encompassed the institution's physical, administrative, and scientific scope, which earned it the name Museu Paraense de História Natural e Etnografia. It earned new regulations, new facilities - suitable for scientific research, museum activities, and science communication - and a journal, the Boletim do Museu Paraense de História Natural e Etnografia, which circulated through barter between domestic and international institutions and wherein Snethlage would publish several articles. The museum's regulation made explicit Goeldi's scientific project to transform the institution into a specialized institute to research the nature of Amazon, particularly its flora and fauna. To give life to his intentions, the director demanded that hired professionals had training in

\footnotetext{
${ }^{22}$ Sanjad, A coruja de Minerva, 378, 379. For more on Emílio Goeldi and the Museu Paraense see this and other works by Nelson Sanjad, such as Emílio Goeldi (1859-1917): A ventura de um naturalista entre a Europa e o Brasil (Rio de Janeiro: EMC, 2009).
} 
the natural sciences -an educational formation non-existent in Brazil at the time - published articles, and exhibit "scientific probity."23 According to Sanjad, other requirements not expressed in the regulations included the origin of candidates and German language skills, which eventually led to the creation of a team of scientists born and trained in central Europe, who could speak to each other not only in the same language, but also in the same scientific terms and with ties to a network of central European scientific institutions ${ }^{24}$ Goeldi would directly contact the candidates for recruitment or make use of his relationship network in European universities and museums, as it happened when hiring Emilie Snethlage through Anton Reichenow.

Science practiced in museums and universities within German Europe at the time was marked by a great competition for positions. Lewis Pyenson underscores the fact that during the nineteenthand early twentiethcenturies, these scientific institutions formed more professionals than the labour market could absorb. This was further enhanced since Germany only attained political unity in 1871, long absent from the colonial enterprises of countries such as France and England, which ensured British and French researchers positions in colonial administrations and access to remote areas under State protection. Moreover, scientists who held key positions in museums and important academic chairs occupied their positions for an extremely long time, sometimes for half a century, which also limited the number of available positions ${ }^{25}$ In her decision to move to the Amazon, Snethlage certainly considered these conditions and, accordingly, her judgement proved correct as she had the opportunity to pursue a full scientific career in Brazil 26

By working in the Amazon, Snethlage added Goeldi's entire network and other Museum professionals to her sociability network. Hired as a zoology assistant, she soon continued with a project cherished by the director and part of the work program designed for the Museum: the systematization of scientific knowledge about the Amazon 27 This specifically referred to a faunal survey of the Amazon birds, a project initiated by a zoology assistant who had previously occupied Snethlage's position, the Swiss Gottfried Hagmann (1874-1946). Tutored by Goeldi, Hagmann examined the volumes of

\footnotetext{
${ }^{23}$ Regulamento, 1894 quoted in Sanjad, A coruja de minerva, 205.

${ }^{24}$ Sanjad, A coruja de minerva, 205.

${ }^{25}$ Lewis Pyenson, "Functionaries and seekers in Latin America: missionary diffusion of the exact sciences, 1850-1930," Quipu 2 (1985), 387-420.

${ }^{26}$ Mariza Corrêa, Antropólogas e antropologia (Belo Horizonte: Editora UFMG, 2003), 93.

${ }^{27}$ For more on this project by Goeldi, see Nelson Sanjad, "Emílio Goeldi (1859-1917) e a institucionalização das ciências naturais na Amazônia," Revista Brasileira de Inovação 5 (2006): 455- 477.
} 
the Catalogue of the Birds in the British Museum (1874-1898), searching for information on birds found in the Amazon region, comparing this data with information from travellers and naturalists experts. From this point Snethlage assumed the work, which resulted in the 1914 publication on the Amazonian birds entitled "Catálogo das aves amazônicas," "containing all the specimens described and mentioned until 1913."28 Information obtained by Snethlage during her early years in the Amazon-i.e., the information on the taxonomy, biology, and biogeography of the birds collected, the material already existing in the Goeldi Museum and in other museums - was added to the work developed by Hagmann. The historiography of science has devoted itself to museum catalogues, considered an important extension of collections, true "paper museums" or "pocket museums."29 The "Catálogo" was not limited to the existing material in a museum, but rather it was a comprehensive faunal inventory of the occurrence of a class of animals within a particular region, as was common in zoological studies. Thus, the Goeldi Museum collection was integrated into other museums in other parts of the world.

A list of works used to prepare the "Catálogo" and Snethlage's acknowledgments in the introduction allow us to reconstruct the plot of the scientific sociability network supporting the research 30 Her first gratitude goes to Goeldi; Count Berlepsch earns mention for his "invaluable services (...) in species identification and nomenclature."31 Berlepsch was a renowned taxonomist and a major private collector and became one of Snethlage's

\footnotetext{
${ }^{28}$ Emilie Snethlage, "Catálogo das aves amazônicas, contendo todas as espécies descritas e mencionadas até 1913," Boletim do Museu Paraense de História Natural e Ethnographia 8 (1914): 1-530.

${ }^{29}$ Regarding catalogues, museums and collections see Maria Margaret Lopes, "Viajando pelo campo e pelas coleções: aspectos de uma controvérsia paleontológica," História, Ciências, Saúde - Manguinhos, 8 (2001): 881-897. The expression "paper museums" is used by Rudwick (2000) and "pocket museums" by Hellyer (1996), mentioned in Lopes, "Viajando pelo campo e pelas coleções," 885.

${ }^{30}$ Acknowledgements are in Emilie Snethlage, "Catálogo," 3. For a detailed analysis of the context and scientific controversies surrounding ornithology at the time, especially those involving the issue of trinomial nomenclature, see Erwin Stresemann, Ornithology: From Aristotle to the present (Cambridge Mass.: Harvard University Press, 1975).

${ }^{31}$ Snethlage, "Catálogo," 3. Hans von Berlepsch had studied zoology in Leipzig and Halle. In 1872, he began what would become the largest private ornithological collection in Germany at the time, which grew through purchases and exchanges with private collectors and institutions. His interest was focused on exotic species, particularly in South America and his collections were later incorporated into the Senckenberg Museum in Frankfurt/Main. Erwin Stresemann, "Berlepsch, Hans Hermann Carl Ludwig Graf von," in Neue Deutsche Biographie 2 (1955), 96ff [Online]. Available in: http://www.deutschebiographie.de/ppn117588563.html. Accessed 30/08/2015.
} 
most important interlocutors in Europe, mentor to important German ornithologists such as Ernst Hartert (1859-1933) and Carl (Charles) Eduard Hellmayr (1878-1944), who were also part of Snethlage's contact network and mentioned in the acknowledgments in the "Catálogo." Hartert ${ }^{32}$ who had participated in the publication of the British Catalogue of the Birds was the director of the private Tring Museum, England, and earns mention alongside its owner, Walter Rothschild (1868-1937) ${ }^{33}$ As for Hellmay an expert on neo-tropical birds was an ornithology curator at the Zoologische Staatssammlung München. He had studied in Vienna the birds collected by Johann Natterer (1787-1843) 35 the birds collected by Johann von Spix in Munich (1781-1826), and in Paris, the birds collected by Al-

\footnotetext{
${ }^{32}$ Despite not having an academic background, Ernst Hartert had the opportunity to acquire extensive knowledge of zoology from his many trips, taking part in expeditions as a zoologist, such as in 1885/86 to current Northern Nigeria (Hausaland), or as independent collector, such as in $1887 / 89$ across south East Asia. He worked initially in the Senckenberg Museum in Frankfurt/Main, and later prepared a volume of Catalogue of the Birds. In 1892, he was appointed director of the Tring Museum, expanding their collections and exponentially amplifying the museum's importance. He was an ardent supporter of trinomial nomenclature, used to denote species subdivisions, initially employed by ornithologists and then by biology as a whole. Erwin Stresemann, "Hartert, Ernst Johann Otto," in Neue Deutsche Biographie 7 (1966), 711ff [Online]. Available in: http://www.deutsche-biographie.de/ppn116490462.html. Accessed 30/08/2015.

${ }^{33} \mathrm{~A}$ unique character, Baron Leonel Walter Rothschild was active in several fields, including politics (especially the Zionist cause, having been the recipient of the Balfour Declaration). He expressed his passion for zoology with the organization of the Tring $\mathrm{Mu}-$ seum, in 1892, which held one of the largest private natural history collections of all time. The ornithological collection in particular rivaled the British Museum (Natural History) collection in London. He funded several collection trips to enlarge collections and hired renowned professionals for his museum, including Hartert. The bird collection was sold in 1932 to the American Museum of Natural History and the Tring Museum, now part of the Natural History Museum, houses, since 1972, the ornithology collection of the old rival institution. On Rothschild and the Tring Museum see also Miriam Rothschild, Dear Lord Rothschild: Birds, Butterflies \& History (Philadelphia: Balaban, 1983).

${ }^{34}$ Ornithologist Carl (Charles) Eduard Hellmayr was born in Vienna and studied in Berlin and Vienna. Due to his intense dedication to museum activities, he never finished his studies, but his knowledge led him to take over, in 1908, the position of ornithology curator at the Munich Museum. He became known as "Charles" Hellmayr during the time he worked in the Field Museum of Natural History in Chicago, where he was curator of zoology from 1922 onwards. He participated in 13 of the 15 volumes of the publication Catalogue of Birds of the Americas (1918-1949) and The Birds of Chile (1932). Österreichisches Biographisches Lexikon und biographische Dokumentation (ÖBL). ÖBL 1815-1950, vol. 2 (Lfg. 8, 1958), p. 263ff. Available in: http://www.austriaca.at/oebl/oebl_H/Hellmayr_Carl-Eduard_1878_1944.xml. Accessed $30 / 08 / 2015$.

35 For more on Natterer see Kurt Schmutzer, "Metamorphosis between field and museum: collections in the making," HoST 5 (2012): 1-16.
} 
cide d'Orbigny (1802-1857), naturalist travellers who visited Brazil in the nineteenthcentury, which made him an especially interesting partner for Snethlage, providing her with "very valuable information regarding different uncertain points in nomenclature and zoogeography." "36 Hellmayr studied Berlepsch's collection in 1904/05, and was in Tring soon afterwards, in $1905 / 06$, which indicates the density of the scientific sociability network, representative of the small world of ornithology collections of the great European museums in the late nineteenth and early twentiethcenturies, where everyone knew and often worked alongside each other. Snethlage's acknowledgments proceed, quoting her former boss in Berlin, Anton Reichenow; the British Museum (Natural History) ornithology curator, author or co-author of 13 of the 27 volumes of the Catalogue of the Birds, Richard Bowdler Sharpe (1847-1909) ${ }^{37}$ Ludwig von Lorenz-Liburnau (1856-1943) ${ }^{38}$, of the Vienna Hofmuseum, and finally Auguste Ménégaux (1857-1937) ${ }^{39}$ of the Muséum National d'Histoire Naturelle, Paris. The mentioned scientists were curators of collections examined by Snethlage during two study trips to Europe in 1907 and 1910 with the objective of identifying specimens recently collected or already belonging to the Goeldi Museum collection ${ }^{40}$ Some of these scientists, such as Hartert, Hellmayr and Berlepsch, had been her

\footnotetext{
36 Snethlage, "Catálogo," 3.

${ }^{37}$ The British zoologist, Richard Bowdler Sharpe, began his scientific career as a librarian of the Zoological Society of London in 1867. His knowledge of birds assured him, in 1872 , an assistant post in the zoology department of the British Museum (NH) and in 1895, as a curator of the ornithology section. He founded the British Ornithologists' Club (BOC) in 1892, to allow members of the British Ornithologists' Union (BOU) to meet regularly, and was editor of the Bulletin of the British Ornithologists' Club, an official organ of the BOC. Known to be a tireless worker, he expanded the bird collections of the British Museum (NH) through purchases and donations; the number of specimens increased from 35,000 in 1872 to 500,000 in 1909. For more on Sharpe see Joel A. Allen, "Richard Bowdler Sharpe," The Auk 27 (1910): 124-129.

${ }^{38}$ Lorenz-Liburnau studied natural sciences at the University of Vienna. He worked as curator at the mammals and birds section of the Hofmuseum (currently Wiener Naturhistorisches Museum) from 1888, becoming in 1912 the director of the zoology department. He was known for his dedication to the mammal collection, especially ovine and caprine animals. Moriz Sassi, "Hofrat Prof. Dr. Ludwig von Lorenz-Liburnau", Annalen des Naturhistorischen Museums in Wien, vol.55 (1944-1947), pp. 177-179.

39 Henri Auguste Ménégaux, a French zoologist, worked at the Muséum National d'Histoire Naturelle. In 1906, he devoted himself to ornithology, becoming one of the leading French specialists in the field; he founded in 1909, along with Louis Simon Denis (1863-1914), the Revue Française d'Ornithologie. He encouraged the creation of the Société Française d'Ornithologie, founded in 1923, and the journal became its official organ.

${ }^{40}$ Sanjad et al., "Um inédito relato de viagem," 213.
} 
interlocutors on different occasions. Goeldi had certainly suggested many of these names, but Snethlage appeared in this network through her own right. The "Catálogo," built from her own ornithological fauna researches in the Amazon region and integrated, through the species mentioned therein, to the work developed by major European ornithologists, was crucial to the construction of Emilie Snethlage's legitimacy as an expert ornithologist in Amazon birds.

However, as we have seen, Snethlage's network included other people in addition to scientists active in European museums. At the Museum, for example, she had the company of two colleagues, Anna de Aragão Carreira (1894-?) and Abigayl Esther de Mattos (1889-1958), hired in 1907 for administrative services, a "unique experience in Pará," which resulted in "wholly satisfactory results for the Museum, to which I praise the zeal and dedication from said employees in the performance of their duties" in the words of the director replacing Goeldi in 1907, the Swiss botanist Jacques Huber (1867-1914) 41 The assistants accompanying Snethlage on her trips were also Museum employees and I shall return to them when I address the fieldwork (figures 2 and 3).

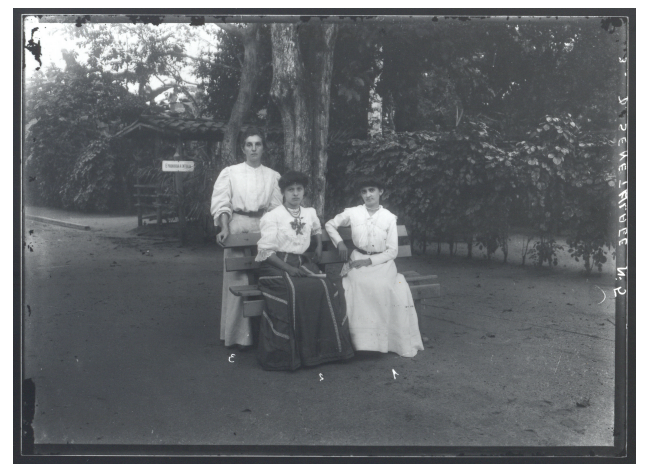

Figure 2: Women employees of the Goeldi Museum, c.1917 (MCTI/Museu Paraense Emílio Goeldi archive)

When Goeldi returned to Europe in 1907, Snethlage became head of the Zoological Section, a position that included the administration of the zoo, which was part of the museum. When the new director, Jacques Huber, died in 1914, Emilie Snethlage took over the institution, according to Cunha, "the first woman to assume the direction of a scientific institution in South America." ${ }^{42}$ As noted by Mariza Corrêa, a contributing factor to

\footnotetext{
${ }^{41}$ Huber apud Sanjad, A coruja de Minerva, pp. 425-426.

${ }^{42}$ Oswaldo Cunha, "Maria Elizabeth Emília Snethlage," in Talento e atitude: estudos
} 


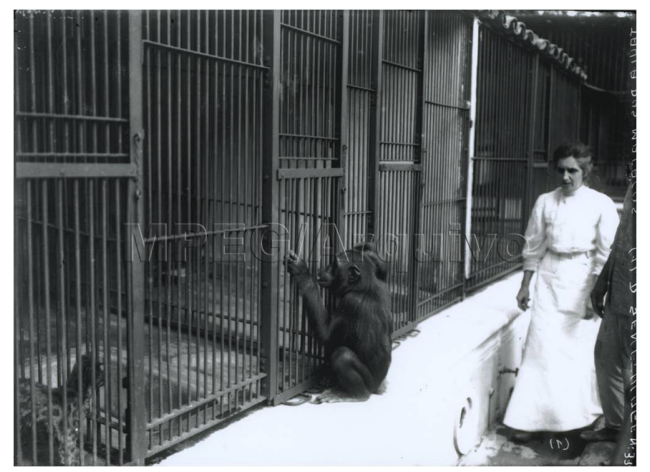

Figure 3: Emilie Snethlage at the Goeldi Museum Zoo (MCTI/Museu Paraense Emílio Goeldi archive)

Snethlage's nomination was the fact that, at that moment, she was the employee with the highest scientific degree ${ }^{43}$ Professionally speaking, the period that followed was extremely difficult for Snethlage. The end of the financial boom brought by the rubber extraction coincided with the beginning of World War II. In 1917, with the declaration of belligerence against Germany by Brazil, it became impractical to maintain a citizen of German origin in the direction of a Brazilian scientific institution, and Snethlage was removed as Museum director, though she remained Head of the Zoological Section. In 1918, hostilities increased between the two countries and Snethlage was ultimately removed from the institution. With the end of the war, she reassumed her prime positions, the Zoological Section, and the Museum direction in 1919 ${ }^{44}$ However, Pará's political and economic situation had suffered drastic changes compared to the beginning of the century. Economic recession contributed to the end of political support for the museum, which Goeldi had profitably capitalized for the institution. The penultimate foreign scientist in the team, the Austro-Hungarian Adolpho Ducke (18761959), an entomologist and botanist, had left Belém for Rio de Janeiro in 1918. The world in which Snethlage had a defined social place, the Goeldi Museum, where she was a scientist in a group of foreign researchers, had lost importance in Belém's social imaginary in the 1920s. Snethlage's singularities, a woman, a scientist, and a foreigner, living away from her family,

biográficos do Museu Emílio Goeldi, I , ed. Oswaldo Cunha (Belém: Museu Paraense Emílio Goeldi, 1989), 83-102, on p.84.

${ }^{43}$ Mariza Corrêa, "A doutora Emília e a tradição naturalista," Horizontes Antropológicos 1 (1995): 37-53, on pp. 47-48.

${ }^{44}$ Cunha, "Maria Elizabeth Emília Snethlage," 93. 
were met with estrangement by the local society.

In 1922, a city newspaper alleged that women "of dubious life" were visiting the lodgings of single employees at the museum as well as other misuses, such as the diversion of food from the municipal slaughterhouse, destined to animals, to feed poorer employees and their families ${ }^{45}$ Snethlage was accused, within an ambivalent record of her social functions, of being guided by emotion and compassion in the case of food diversion to employees as well as of being too permissive and unable to impose the necessary discipline on the workforce regarding the "women of dubious life." In other words, she was being accused of acting like a woman when it was expected of her to perform a "man's job" and uphold law and order in the institution. Dismissed of her administrative duties by the government, she remained Head of the Zoological Section until the end of 1921. In the following year, at the invitation of the National Museum director, Doctor Bruno Lobo (1884-1945), born in Pará, she moves to Rio de Janeiro and works as a travelling naturalist.46 The Goeldi Museum, in turn, witnesses a period of stagnation from the 1920s on, abandoned by the government and hit hard by the economic depression. This situation would only change in the 1950s, when it was considered a scientific knowledge centre on the Amazon, absorbed by the Union and linked in 1955 to the then National Research Council - CNPq (currently the National Council for Scientific and Technological Development) ${ }^{47}$

The National Museum in Rio de Janeiro was tremendously different from Museu do Pará, starting from its institutional history. During the eighteenthcentury, the Natural History House in Rio de Janeiro-known as "House of Birds" - functioned as a trading post, collecting, preparing, and sending natural history specimens to Lisbon. According to Lopes, the Royal Museum in its initial phase, founded by Dom João VI in 1818, was aligned with the same design as the House of Birds. Through these institutions, the Portuguese State performed the recognition of its natural wealth in its overseas territories, and later - with the court transferred to Rio de Janeiro in 1808 - of the entire Brazilian territory ${ }^{48}$ Known as the Imperial National Museum in 1824 and the National Museum in 1890, the institution began to receive, throughout the nineteenthcentury, materials from

\footnotetext{
${ }^{45}$ Cunha, "Maria Elizabeth Emília Snethlage," 94.

${ }^{46}$ Cunha, "Maria Elizabeth Emília Snethlage," 94.

47 Sanjad, A coruja, 377.

${ }^{48}$ For more on this subject see Maria Margaret Lopes, O Brasil descobre a pesquisa científica: os museus e as ciências naturais no século XIX (São Paulo: Hucitec, 1997), chap. 1.
} 
throughout the country sent by Brazilian and foreign naturalists and by state administration employees, as well as foreign scientific objects obtained through gifts, purchases, or exchanges, consolidating itself as a "general museum," a "metropolitan Museum of encyclopaedic and universal nature," a characteristic that remains to this day 49 Along the way, institutional interests and emphases witnessed variations. Since its early existence, albeit especially from the mid-nineteenthcentury, when the Brazilian Empire undergoes a political strengthening through the consolidation of an agrarian and slave economy, the museum played the role of the State's advisory body for matters pertaining to mining and agriculture. In the second half of the nineteenth century, educational and scientific activities were increased, which became further specialized with a focus on chemistry and geology with the aim of improving the country's development of natural resources. Another important research area was anthropological studies, which began as early as the first half of the century and implemented from the 1870s onwards, following the consolidation of this subject field. Such an emphasis on anthropology would suffer opposition from scientists such as Goeldi or the German zoologist Hermann von Ihering (1850-1930), who worked in the institution in the late nineteenthcentury; unhappy with the fact that the zoological studies institution did not receive due support, among other complaints, they left the museum in the early 1890s 50

Regarding Snethlage's work, the difference in the institutional profile of the Belém and Rio de Janeiro's museums, between a "specialized" and "metropolitan" museum, was particularly felt in the lack of an extensive and scientifically organized ornithological collection in Rio de Janeiro. The National Museum's ornithology section was founded in 1915.51 There was stark contrast, therefore, as to the results from seven years of work under the scientific guidance of the National Museum's ornithology section and the consequences from twenty years of work of the Goeldi Museum's ornithological section. Moreover, the existing technical literature in the National Museum was deficient when compared to the northern museum. In several works published during her stay in Rio de Janeiro, Snethlage complains about the lack of material available for comparing specimens and the lack of adequate literature, which greatly hampered her work. ${ }^{52}$

\footnotetext{
${ }^{49}$ Lopes, O Brasil, 324-325.

${ }^{50}$ Lopes, O Brasil,108 and 199.

${ }^{51}$ Ornithology sector of the National Museum. Available at: http://www.ornitologia.mn.ufrj.br/colecao.html. Accessed 30/08/2015.

${ }^{52}$ For a comparison of the ornithological collections of both institutions during Snethlage's lifetime, see Miriam Junghans, "Abrindo as gavetas," in Colecionismos, práticas de
} 
Her arrival at the National Museum, however, also had its positive aspects, such as new work fronts through the expansion of the researched geographic area and the fact that she was, due to her transference to Rio de Janeiro, exempt from the administrative responsibilities that had consumed much of her time and energy in the Pará Museum. Moreover, Snethlage's scientific sociability networks would gain new dimensions with the inclusion of several Brazilian colleagues, including women scientists. At the time, two other women worked in the National Museum, who would obtain prominent positions within Brazilian science and society. Heloisa Alberto Torres (1895-1977) had joined the museum in 1918 as an intern. Daughter of Alberto Torres (1865-1917), a politician and intellectual, she would become the first woman to head the institution between 1938 and 1955. Bertha Lutz also had a surname that could immediately evoke her father's work, the scientist Adolpho Lutz (1855-1940). With a degree in Natural Sciences from Université Paris-Sorbonne, Bertha Lutz began working at the National Museum in 1919 and, in addition to her women's rights political activism, she authored an expressive scientific production, which has recently been investigated by the social history of science ${ }^{53}$ In the 1920 s, therefore, the National Museum had three women scientist within its staff, placing it in a prominent position at the time among Brazilian institutions dedicated to scientific production when it came to female participation. Even in such a context, Snethlage's social status was different from her female peers. The only reputation she could rely on was established during years of work in northern Brazil, through her fieldwork, published works, and administrative positions. Bertha Lutz and Heloísa Torres' surnames may have often been used against them $[54$, but it undoubtedly eased their socialization in the pre-

campo e representações, ed. Maria Margaret Lopes and Alda Heizer (Campina Grande: Eduepb, 2011), 61-73.

${ }^{53}$ For more on Bertha Lutz, see, for example, Maria Margaret Lopes, "Vencer barreiras', até quando? Aspectos da trajetória científico-política de Bertha Maria Júlia Lutz (1894-1976)," in Ciência, tecnologia e gênero: desvelando o feminino na construção do conhecimento, ed. Lucy dos Santos, Elisa Ichikawa; and Doralice Cargano (Londrina: Iapar, 2006), 205-232; Maria Margaret Lopes, Lia Gomes P. de Souza, "Mulheres nas ciências naturais: produção científica de Bertha Maria Júlia Lutz (1894-1976) a partir da década de 1940," in Gênero em movimento: novos olhares, muitos lugares, ed. Cristiani Silva, Gláucia Assis, and Rosana Kamita (Florianópolis: Mulheres, 2007), 59-72; Mariana Moraes de Oliveira Sombrio, "Traços da participação feminina na institucionalização de práticas científicas no Brasil: Bertha Lutz e o Conselho de Fiscalização das Expedições Artísticas e Científicas do Brasil, 1939-1951" (MA diss., University of Campinas, 2007).

${ }^{54}$ As in Lima Barreto's (1881-1922) acid chronicles against feminism, analyzed by Maria Margaret Lopes, "Proeminência na mídia, reputação em ciências: a construção de uma feminista paradigmática e cientista normal no Museu Nacional do Rio de Janeiro,"

HoST - History of Science and Technology 10, pp. 71-101 DOI $10.1515 /$ host-2016-0004 
dominantly male scientific environment of the time. Among her National Museum co-workers, two other colleagues besides Bertha Lutz would become personal friends: anthropologist Edgard Roquette-Pinto (1884-1954), director of the National Museum between 1926 and 1935, and zoologist Alípio de Miranda-Ribeiro (1874-1939). Snethlage paid homage to Roquette-Pinto by naming a bird species after him in 1928: Phylloscartes roquettei. RoquettePinto was a renowned intellectual in scientific communication and education, among other fields, having also studied medicine and taught at the National Museum since 1906. His participation in the Rondon Commission (1907-1915) gave origin to important anthropological works. ${ }^{55}$ He was also a founding member in 1916 of the Brazilian Society of Sciences (renamed in 1921 to Brazilian Academy of Sciences) ${ }^{56}$ Miranda-Ribeiro, also a member of the Academy of Sciences, had participated in the Rondon Commission between 1908 and 1909. Integrated into the evolutionary theory debates of the period, he shared with Snethlage an interest in zoogeographical, ecological, and biological issues, which certainly contributed to bringing them together 57 A recognition of the importance in Snethlage's scientific work arose by way of these colleagues with an invitation to join the Brazilian Academy of Sciences in 192658

In Emilie Snethlage's case, her social practices involved an insertion within a network of scientific sociability, which included important names of the natural sciences of the early twentiethcentury in Europe and Brazil, the professional activity in three natural history museums, publications in scien-

História, Ciências, Saúde - Manguinhos 15, (2008): 73-95.

55 Between 1907 and 1915, the Commission of Strategic Telegraph Lines from Mato Grosso to Amazonas (Comissão de Linhas Telegráficas Estratégicas de Mato Grosso ao Amazonas), better known as the Rondon Commission, ran through the current Brazilian states of Mato Grosso, Rondônia and Amazonas. Its main goal, to establish telegraph lines for promoting the integration of these areas with other Brazilian regions was accompanied by scientific research on the covered territories and on human groups inhabiting therein. For more on the Rondon Commission, see Dominichi Miranda de Sá, Magali Romero Sá and Nísia Trindade Lima, "Telégrafos e inventário do território no Brasil: as atividades científicas da Comissão Rondon (1907-1915)," História, Ciências, Saúde - Manguinhos 15 (2008): 779-810 and Arthur Caser and Dominichi Miranda de Sá, "O medo do sertão: a malária e a Comissão Rondon (1907-1915)," História, Ciências, Saúde - Manguinhos 18 (2011): 471-497.

${ }^{56}$ For more on Roquette-Pinto, see Nísia Trindade Lima and Dominichi Miranda de Sá, ed., Antropologia brasiliana: ciência e educação na obra de Edgar Roquette-Pinto (Belo Horizonte / Rio de Janeiro: Editora UFMG / Editora Fiocruz, 2008).

${ }^{57}$ For more on Miranda-Ribeiro, see Sá and Lima, "Telégrafos."

${ }^{58}$ See Alípio de Miranda-Ribeiro, "Discurso de recepção da Dra. Emília Snethlage na Academia Brasileira de Sciencias e em nome desta proferido em sessão de 26 de outubro de 1926," Boletim do Museu Nacional 12 (1936): 77-85. 
tific journals and books, and participation in associations such as the Brazilian Academy of Sciences and the Society of Woman Geographers, where she was member between 1926 and 1931. These activities partially accounted for the legitimacy acquired by the scientist. Another dimension, however, was also of fundamental importance in establishing the recognition of her work, as we shall see.

\section{Fieldwork}

With her intense activities in bird observation and collection, Emilie Snethlage indelibly associated her name to fieldwork research in Brazil in such a way that the lower Amazon region - the lower third of the river and its tributaries - which she explored during the time she lived in Pará, is currently known among ornithologists as the "Snethlage's area." Fieldwork, being an important part of the research in natural sciences, has received the attention of science historians, generally analysed in contrast to lab research, for some time considered the loci par excellence of scientific knowledge production. Science produced in these locations was initially seen as "neutral" and universal, i.e., devoid of local biases and, ideally, capable of being equally reproduced anywhere in the world and yielding the same results. In the 1980s, social studies on science began to consider the aspects and meanings of the locality to scientific work, which led to the investigation of other spaces such as museums, collections, libraries, herbaria, botanical and zoological gardens, as well as fieldwork itself 59 As analyzed by Robert Kohler $\sqrt{60}$, while they are interconnected instances, scientific research in the actual natural environment presents important differences from the one conducted in laboratories or museums and inevitably carries the traits of its production space. In contrast to restricted and controlled environments, the field is an open space, often with undefined limits and permeable to innumerable influences, many of which are foreign to the scientific work itself. Moreover, access to the field is possible to all kinds of people, unregulated, and difficult to control. This factor is of great importance in acknowledging the legitimacy of science performed during fieldwork because the scientist must use other

\footnotetext{
${ }^{59}$ Among the several authors who have studied the issue, Dorinda Outram, "New spaces in natural history," in Cultures of natural history, ed. Jardine, Secord and Spary,249265; Lorelai Kury, "Viajantes naturalistas no Brasil oitocentista: experiência, relato e imagem," História, Ciências, Saúde - Manguinhos 8 (2001): 863-880; Bruno Latour, A esperança de Pandora (Bauru: Edusc, 2001); Lopes, "Viajando pelo campo"; Robert Kohler, "Place and practice in field biology," History of Science, 40 (2002): 189-210.

${ }^{60}$ Kohler, "Place and practice."
} 
legitimization strategies. To analyze how Snethlage's fieldwork contributed to the construction of her legitimacy as a scientist, I shall examine aspects pertaining to the organization and execution of her expeditions, some daily details of her field practices, and the social connections that enabled her expeditions and work.

In the tradition of natural history, especially in the eighteenth and nineteenth centuries, it had become customary in the career of European "men (and women) of science" to undergo at least one great expedition trip in their early professional career to some faraway place, publish the results, and then dedicate themselves to office work in a scientific institution, such as a museum or university. With the transformations that accompanied the emergence of the disciplinary field of biology, as we currently know it, fieldwork remained of paramount importance, but the status of research trips suffered transformations. Rather than long trips early in their career, it became customary for scientists to undertake several smaller trips according to the research project at the time. In Emilie Snethlage's professional career, fieldwork was of fundamental importance and, as we shall see, the characteristics of her research expeditions allows us understand them as a middle ground between the natural history tradition - which included an interest in nature's "three kingdoms" and human groups found during the trips - and biology.

Fieldwork, which may include the killing and preparation of specimens, had long been regarded as an impediment to the effective participation of women in the natural sciences. Snethlage may have been inspired, however, by the trajectory of other women who, facing prejudices, conducted naturalistic trips, such as the British Mary Kingsley (1862-1900), who explored Africa's west coast and successfully published her travel reports, or German Amalie Dietrich (1821-1891), who extensively travelled Australia between 1863 and 1872; such women obtained their livelihood by selling collected specimens to natural history institutions. Other women before Snethlage had also covered the Amazon region: in 1888, Princess Theresa of Bavaria (1850-1925), Doctor honoris causa from the University of Munich, had conducted extensive collections in this region along with her chaperone and two assistant: ${ }^{61}$;in 1895, Marie-Octavie Coudreau (1870-1910), cartographer, designer and topographer, along with her husband, French explorer and geographer Henri Coudreau (1859-1899), conducted research in the region and, to honour the contract with the government of Pará after her

\footnotetext{
${ }^{61}$ Hadumond Bußmann, Eva Neukum-Fichtner, "Ich bleibe ein Wesen eigener Art': Prinzessin Therese von Bayern" (München: Ludwig Maximilians Universität, 1997).
} 
husband's death, she assumed control of the expeditions and published the results 62 These women differed from Snethlage mainly by their status as temporary visitors in a society in which she had a more permanent participation. Moreover, such women were legitimized, respectively, by possessing a title and belonging to nobility associated with the most important houses of Europe and also, in the case of Coudreau, due to a professional mission assigned to her husband, she then having assumed the position after his death. Snethlage's legitimacy, on the other hand, was being established through different ways.

Once she arrived in Pará in 1905, Snethlage dedicated her time to familiarize herself with the region where she would work in the following years. Her first collection field expeditions covered the aforementioned lower Amazon region in order to catalogue its species, which would eventually comprise the "Catálogo das aves amazônicas." Therefore, two months after her arrival in Belém in October 1905, Snethlage toured the northeast of Pará, in Santo Antônio do Prata, where she conducts collections over three weeks. Later, in December, she travels to Marajó Island, where she remains for four weeks. In early 1906 she visits, for a further two weeks, the region of Monte Alegre, on the Amazon's left bank. These locations have extremely diverse geographical, botanical, and faunal characteristics. Santo Antônio do Prata was located amid the solid ground forest. Marajó Island had, at least in the region covered by Snethlage, an area of fields. In Monte Alegre, located near the Maicuru River on the left bank of the Amazon, the forest bordered the river. These three locations allowed the scientist to learn, from first-hand experience, the characteristics of different geographical formations and the variety of their bird faunas. It soon became clear to Snethlage that watercourses were of prime importance in the bird distribution, with differences in the occurrence of species on either side of a river. Thus, in addition to facilitating transportation, rivers gained major importance in her zoogeographic researches, i.e., the study of the spatial distribution of species ${ }^{63}$ Moreover, through her naming of rivers we may have an idea of her researches. During the years she remained in northern Brazil, Snethlage conducted collections in rivers south of the Amazon (Tapajós, Xingu, and Tocantins) and many of its tributaries, having also explored northern rivers (Jari, Maicuru, Jamundá, in addition to the Negro River). Furthermore, she conducted excursions in the

\footnotetext{
${ }^{62}$ For more on the Coudreau couple, see Durval de Souza Filho, "Os retratos dos Coudreau" (MA diss., Federal University of Pará, 2008).

${ }^{63}$ For further information on the biogeographic analyses on Snethlage, see Bertha Lutz, "Emilie Snethlage (1868-1929)," in Relatório anual do Museu Nacional, pelo diretor José C.M. Carvalho (Rio de Janeiro: Museu Nacional, 1957), 39-43.
} 
outskirts of Belém, on Marajó Island and then returned to the east of Pará, where she explored the region of the Guamá River and the Santo Antônio do Prata surroundings, at the Maracanã River. In 1910, she travelled to Ceará, where she studied the hinterland's (sertão) bird fauna, establishing comparisons with the birds found in the rainforest. This marked the beginning of the geographical expansion of her study field, which intensified after her relocation to Rio de Janeiro in 1922, when she began to explore other regions of Brazil. Her first major expedition as a National Museum naturalist was to Maranhão, which marks the continuation of her research project. Having noticed that rivers play a significant role in the distribution of species, she expected the coast would also play an important role; therefore, in 1923, in the company with her nephew Emil Heinrich Snethlage, she travelled to several places along the Maranhão coast for five months. While researching the bird fauna of that state, she intended to intensify her studies on the wildlife boundaries between the forest and the sertão. In 1925 she visited Espírito Santo (Doce River) and Minas Gerais, and Bahia in 1926 (São Francisco River). In 1927, the journey began in the state of São Paulo and continued along part of Goiás and Mato Grosso (Araguaia River, Bananal Island). In 1928, she travelled through southern Brazil, from Paraná to Rio Grande do Sul (Uruguay River and Paraná River). These trips were based upon the idea of writing a major work on the Brazilian bird fauna, a catalogue of Brazilian birds, and were complemented with a research trip to Europe between 1924 and 1925, during which she revisited several natural history museums for comparative studies ${ }^{64}$ For this new catalogue, it would be necessary to complement the research in northern Brazil, which was still incomplete. She wanted to once again travel to the Negro River and sail up the Branco River, and study the bird fauna of Brazil's borders with Colombia and Venezuela. ${ }^{65}$ Moreover, she never had the opportunity to study the birds of one of the major tributaries south of the Amazon, the Madeira River. On her final expedition trip begun in 1929, Emilie Snethlage died in her hotel room, by all indications of a heart attack 66

When she passed away, in Porto Velho, Snethlage was alone, as she commonly travelled at the service of the National Museum, on trips that could last months, during which she solely relied on guides hired in the visited locations. During the period in which she worked in northern Brazil, her expeditions for collecting specimens lasted a few weeks, as we have seen. At

\footnotetext{
${ }^{64}$ Cunha, "Maria Elizabeth Emília Snethlage," 95.

${ }^{65}$ In "Emilie Snethlage (1868-1929)" Lutz refers to Brazil's borders with Colombia and Ecuador, but it is clearly a lapsus calami.

${ }^{66}$ E.-H. Snethlage, "Dr. Emilie Snethlage zum Gedächtnis," 123.
} 
that time, Snethlage used to travel accompanied by an assistant, who helped her with the hunting and preparation of specimens. In general, there is little documented information on the names of these assistants or helpers, which occasionally surfaces when Snethlage interrupts the scientific detachment on some articles: Oscar Rodrigues Martins, Francisco de Queiroz Lima, or João Baptista de Sá (18?-1909), paid homage to by Snethlage with the classification of Euscarthmus iohannis, a flycatcher with an olive-green plumage. The long hours shared, the travels and their adventures and mishaps, led to friendly relationships between scientist and assistants, some of whom she treated like her children, as can be read in a 1907 report 67

I am still worried about my little Oscar, who has been tremendously valuable and willing. He landed with a strong cold, coughing as if tubercular and complained yesterday of severe headaches. He's shown improvements today, but for me, he should go as little as possible into the woods, and within eight days or more I might install my accommodations in Alcobaça [Tucuruí] (or Baião), where I may at least rely on a doctor.

In addition to the affection shown toward "Little Oscar," Snethlage always expressed recognition and respect in her articles for those enabling or helping her across unknown and possibly dangerous territories. This greatly differs from the vast majority of male scientists of her time, whose reports rarely mention, let alone name, field assistants. Thus, when describing a journey she conducted on foot in 1909, among the Xingu and Tapajós rivers, a region previously unknown to science, and which had great impact on the national and international scientific community ${ }_{68}^{6}$ Snethlage names the native Curuahés (Kuruaya) Indians who accompanied her, a decidedly unusual procedure in scientific travel literature: "In addition to myself, we had old man Maitumá with his two wives, Comaicarú and Umarú, João (the only one who knew a few Portuguese words) with his wife Parimarú, Topá, and one other Curuahé, whose name I never got to know.' 69 At the end of the journey, she bids farewell to her "good and faithful traveling companions during four weeks" with "sincere sorrow and much gratitude."70 The Indians received not only personal attention from Snethlage, but also scientific.

\footnotetext{
${ }^{67}$ Sanjad et al., "Um inédito relato de viagem," 201.

${ }^{68}$ Regarding this journey, see Emilie Snethlage, "A travessia entre o Xingu e o Tapajoz," Boletim do Museu Goeldi 7 (1912): 49-92 and Junghans, "Avis rara", chap. 3.

${ }^{69}$ Snethlage, "A travessia," 72.

${ }^{70}$ Snethlage, "A travessia," 88.
} 
She published several articles about them in Brazil and abroad, as well as comparative vocabularies, placing herself, in a way, in the tradition of naturalistic expeditions of previous centuries, during which travellers considered human groups encountered as part of the "natural world," which needed to be studied and recorded 71

In addition to naming her assistants during the time she worked in Belém, Snethlage also mentions the support of owners of farms and rubber plantations, which sought to reduce the burden on travellers by providing shelter, transportation such as horses and canoes, establishing contact with guides, and providing employees to assist the researchers. Many of these owners had ties with local politics, and in the early years of the twentiethcentury, their support to the museum staff was a way of showing cooperation toward a project cherished by the state government, which was certainly advantageous to them. These friendly relationships also demonstrated acceptance of Snethlage's presence as a scientist, in which legitimacy intertwined the respectability acquired by the Museum as well as the reputation earned through her fieldwork (figure 4).

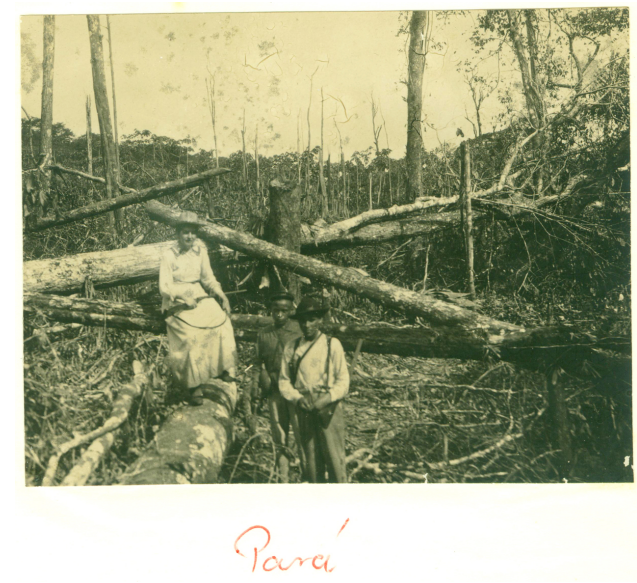

Figure 4: Emilie Snethlage during fieldwork (Personal Archive of the Snethlage Family)

\footnotetext{
${ }^{71}$ In addition to "A travessia entre o Xingu e o Tapajoz", these are the articles by Snethlage on ethnographic themes: "Zur Ethnographie der Chipaya und Curuahé," Zeitschrift für Ethnologie (1910): 612-637; "Vocabulário comparativo dos índios Chipayas e $\mathrm{Cu}-$ ruahé," Boletim do Museu Goeldi, 12 (1912): 93-99; "Nature and man in Eastern Pará, Brazil," The Geographical Review 4 (1917): 41-50; "Die Indianerstämme am mittleren Xingu," Zeitschrift für Ethnologie (1920-1921): 395-427; "Die Flüsse Iriri und Curuá im Gebiete des Xingu," Zeitschrift der Gesellschaft für Erdkunde zu Berlin (1925): 328-354.
} 
In addition to housing availability, other scientific and practical factors guided the choice of places to explore. Locations were chosen according to the occurrence of certain birds, which would allow for the collection of species for illuminating morphological, biological, and zoogeographical topics. The specified region for observations and collections was to be located away from civilization so that diverse and uncommon species could be captured. The decision also took into account the season of the year. It was necessary to consider the rainy season, river floods, and the birds' breeding season. Accessibility was also an important concern. At the service of the Goeldi Museum, steamboats were most commonly used for journeys. Depending on the location, they used trains with passes provided by the state government, which included luggage transportation 72 The trip could then proceed with the aid of canoes, the igarités of the rubber tappers or the small ubás (dugouts) of the Indians, which were also used during explorations, such as the journey across the Iriri and Curuá rivers in 1909 and 1914. One could not forget that, upon returning from expeditions, there would always be more material to transport. Although Snethlage's specialty were birds - their prepared skins did not take up as much space as other zoological collections and did not weigh as much as geological samples - she did not shy away from adding further specimens to the museum's collections, such as rocks or the anteater she won during her trip to the Tocantins River 73

The unpredictability of events during research expeditions, one of the characteristics of fieldwork, accounted for another contributing dimension to Snethlage's legitimacy as a scientist: her bold behaviour and courage in situations that endangered her physical integrity and of her companions. According to Naomi Oreskes ${ }^{74}$ scientific work may be characterized and valued from two mutually exclusive and contradicting images: objectivity and heroism, commonly associated with masculine activities and roles. Objectivity would correspond to the traditional figure of the lab scientist, absorbed in work with no room for subjectivity, in turn considered a female and negative characteristic. A man of great resistance or physical strength, willing to sacrifice and risk everything in search of an ideal, on the other

\footnotetext{
${ }^{72}$ Letter from Emilie Snethlage to the Secretary-General of the State, on 12/05/1917, AMPEG/FES (1914-1921), cx.1, folder 92 and others.

${ }^{73}$ See Sanjad et al., "Um inédito relato," 208.

${ }^{74}$ Naomi Oreskes, "Objectivity or Heroism? On the Invisibility of Women in Science," Osiris 11 (1996): 87-113; also see Miriam Junghans, "Emília Snethlage (1868-1929): o heroísmo como estratégia de legitimação da ciência," in Oitavo Congresso Iberoamericano de Ciência, Tecnologia e Gênero, 5-9 April 2010, Curitiba. Available at:http://files.dirppg.ct.utfpr.edu.br/ppgte/eventos/cictg/conteudo_cd/E2_Em\%C3\%ADlia_Snethlage.pdf. Accessed 30/08/2015.
} 
hand, according to Oreskes, may represent the hero. Heroism would have been associated to scientific work from conquest and exploration expeditions, of which fieldwork would be an updated form. It would thus serve to bring scientific work closer to society, granting the scientist with public admiration and support, and could work as an internalized ideal, making the scientific enterprise exciting, important, and valuable to scientists themselves ${ }^{75}$ Heroism could therefore contribute to the legitimacy of scientific work, especially fieldwork, but it was not commonly associated with the work of women. There are numerous episodes in Snethlage's professional life that could be considered "heroic." We shall limit ourselves to a single paradigmatic event. During a trip across the Iriri River in 1914, Snethlage had her finger bitten by a piranha. Although she attempted to save the phalanx, the wound gangrened, forcing her to remove part of her finger with a machete, since no one among her companions was willing to do so 76 When reporting the episode, Snethlage writes at length about the habits of the different piranha species and their distribution in different river stretches, but says nothing about the outcome of the case 77 Many who have written about Snethlage have recounted this story, however, which became exemplary to underscore the scientist's courage and cold blood 78 How aware was Snethlage of the effect of such events in building her reputation as a researcher? When asked on one occasion if she was not afraid of the dangers to which she was exposed during her travels, she replied that: "That is no way for a German to think!" 79 Therefore, she would rather attribute her fearlessness in face of physical threats to her German origins, in fact, Prussian, evoking stereotypes of Prussian virtues such as courage and bravery. She did seem quite aware, however, that she was a woman performing roles considered to be masculine, as said during a different occasion: "The greatest satisfaction I had (...), was receiving a letter addressed to Mr. Dr. Emilio Snethlage: this convinced me that I had done the work of a man."

\footnotetext{
${ }^{75}$ Oreskes, "Objectivity or heroism?," 103.

${ }^{76}$ E.-H. Snethlage, "Dr. Emilie Snethlage," 126.

${ }^{77}$ Snethlage, 1925a, 348.

${ }^{78}$ E.-H. Snethlage, "Dr. Emilie Snethlage," 126. The piranha episode is remembered in the correspondence between German ornithologists Charles Hellmayr and Erwin Stresemann (Haffer, Ornithologen-Briefe des 20. Jahrhunderts, 328-329), by Helmut Sick (Ornitologia brasileira, 56) and Mariza Corrêa (Antropólogas e antropologia, 223, note 23). Emilie Snethlage's exploration trips are quoted, along with those by Karl von den Steinen (1855-1929) and William Curtis Farabee (1865-1925), by Roosevelt (Through the Brazilian wilderness, 166 and 337); Roquette-Pinto refers in particular to the XinguTapajós crossing (Ensaios brasilianos, 88-89).

${ }^{79}$ Miranda-Ribeiro, "Discurso de recepção da Dra. Emília Snethlage," 80.
} 
According to many authors, including Oreskes, scientific work can often be repetitive and unglamorous. In order to remain motivated, scientists must perceive their activities as part of a larger transcendent project, an important contribution to human knowledge. In such cases, heroism often works as a strong personal motivation factor, which seems to have been Snethlage's case 80

Contrary to what one might imagine from accounts such as the one above, the daily life of her fieldwork was relatively calm and uneventful, as shown by her nephew's account ${ }^{81}$ Once in the chosen region to conduct her collections, Snethlage tried to stay close to farms, family houses, or even isolated huts. The important thing was to be able to arrive swiftly in the "field." 82 Research and specimen collection was generally done in the mornings, due to the habits of the animals and the heat, which in tropical regions greatly increases during the day. Being able to return several times to the same place was crucial, since an ornithologist's work, as part of biology and zoogeography, included observing the occurrence of species, their eating, mating, and nesting habits. It was therefore necessary to monitor some specimens over the course of several days. The afternoon, at the peak of the heat, and the rest of the day, if necessary, were dedicated to the preparation of the collected birds. This included material practices, such as the preparation and identification of skins. First of all, she would write notes on the collected specimens. Afterwards, using materials and equipment she carried in her travels, she would prepare the obtained animals. Snethlage was skilful with the use of instruments such as knives, needles and scissors, cotton, and powdered arsenic, she would rarely take more than half an hour to prepare a specimen, and smaller birds such as hummingbirds could be ready as fast as 15 minutes. The next step in preparation was to write and attach labels to the collected data: the name of the institution and the collector, the specimen number in that collection, the location, collection date, gender, and age of the collection (determined during the dissection), iris colour, legs and beak, stomach contents and any comments deemed relevant. The scientific value of a specimen derives from a combination of the physical object, which in Snethlage's case meant the collected bird skin along with information pertaining to its life habits and location ${ }^{83}$ It is extremely important to record

\footnotetext{
${ }^{80}$ Oreskes, "Objectivity or heroism?," 103.

${ }^{81}$ E.-H. Snethlage, "Dr. Emilie Snethlage."

${ }^{82}$ Details pertaining to Snethlage's field accommodations and on her daily activities can be found in Sanjad et al., "Um inédito relato de viagem."

${ }^{83}$ Anne Larsen, "Equipment for the field," in Cultures of natural history, ed. Jardine, Secord and Spary, 362 .
} 
this information, which is crucial to the classification process, in a clear and concise manner and as quickly as possible. Some of this data, such as the iris colour or stomach contents cannot be identified in a specimen preserved by taxidermy. Others, such as the exact location of the collection site can be easily forgotten or confused. Thus, it became important to attach a label to each specimen. This would be the only way to have reliable information on the collected animal, accessible to anyone handling the specimen, and eventually replicate the find, i.e., return to the site. The prepared sample, along with its label, would then be considered a specimen.

In ornithology, taxidermy, i.e., the preparation of specimens for display or drawer specimens is considered an "artistic" activity, since specimens may have personal and indelible marks that refer back to their authors. These variations, expressed in differences in the specimens' shape and density, occur due to different preparation techniques and the variety of materials used for filling the specimens (such as moss, cotton, burlap, etc.). Although only noticeable to a trained ornithologist eye, the material allows one to reconstruct lost information on the collected the specimen from the collector's identification. Helmut Sick (1910-1991), for example, an ornithologist of German origin who worked in Brazil since the 1940s, used to prepare his specimens in a very peculiar way, which became known as "Castelo Branco," as it bore semblance to the former Brazilian president: the specimens' head was very close to the body, as if the animals had no neck. Specimens object of taxidermic treatment by Snethlage also have traits that distinguish them from others. In order to speed up the preparation process, Snethlage did not sow the wings or the incision in the abdomen for the removal of the insides, which eventually was a signature of the birds prepared by her ${ }^{84}$ This emphasis on practicality had its raison d'être, as Snethlage prepared a considerable amount of skins in the course of her life. Her nephew estimated at 10,000 the number of birds and mammals prepared by Snethlage, currently found in Brazilian, European, and American museum collections. A recent listing, which accounts only bird skins surely prepared by Snethlage and with confirmed locations, features more than 7,500 specimens. From this total amount, 3,027 are registered in Museu Paraense Emílio Goeldi, 1,207 are in Rio de Janeiro's National Museum, 13 in the USP Zoology Museum in São Paulo, and 3,317 in various museums abroad 85

\footnotetext{
${ }^{84}$ Vítor de Queiroz Piacentini, Luís Fábio Silveira and Fernando Costa Straube, "A coleta de aves e a sua preservação em coleções científicas," in, Ornitologia e conservação: ciência aplicada, técnicas de pesquisa e levantamento, ed Sandro von Matter et al. (Rio de Janeiro: Technical Books Editora, 2010), 1-18.

${ }^{85} \mathrm{I}$ am grateful to Fatima Lima for this information, assistant at the MPEG Department
} 
Just as she did with the specimens, Emilie Snethlage also subjected herself to changes in her physical appearance to fit the role of a female scientist. A male scientist would certainly opt for a suitable outfit to face the unpredictability of fieldwork, but for Snethlage this included other variables, even during her activities in the museum. Aware of the ambiguity of her social status, it was important to her to be accepted as a female scientist, especially by other women she encountered during travels, that is, when she dedicated herself to activities commonly considered masculine. Thus, she consciously sought to maintain a sober and feminine physical appearance. In most of the existing snapshots, she appears dressed in skirts (Figures 2 and 3). She wore long pants only when out in the field, or not even then (Figure 4), and kept her hair long, while acknowledging that "the short hair fad would indeed be very comfortable for a naturalist, but (...) the ladies in the countryside could find this odd at first." 86 The importance of social representation in the scientist's clothes or hair becomes explicit, for example, in the presentation made by Alípio de Miranda Ribeiro to the Brazilian Academy of Sciences. Much of the article dedicates itself to underscore Snethlage's courage and bravery, while another section dedicates itself to the description of the physical aspects of the "affable silver-haired little lady." According to him 87

[Snethlage] wears her hair like Sophia Kowalewsky - old fashioned - and wears the stern hat of elderly women; her clothing does not dazzle in predicament excesses, but pleases us in the severity of its form. One may occasionally see a semblance of a girl's choice, in the flowers on her hat or in how she organizes fashion; but sobriety dominates her ways, simplicity accentuates her constant predilection -zoology.

To work as a female scientist and to be accepted in social and scientific environments, Snethlage consciously and permanently sought to adapt her physical appearance to contemporary manners, even when it meant sacrificing practicality, such a crucial dimension in fieldwork. Thus, we may understand bodily practices as the expression of the encounter and the sum of social and material practices that contributed in establishing her legitimacy as a scientist.

\footnotetext{
of Ornithology.

${ }^{86}$ Quoted on Roquette-Pinto, Ensaios brasilianos, 89.

${ }^{87}$ Miranda-Ribeiro, "Discurso de recepção da Dra. Emília Snethlage," 81.
} 


\section{Conclusion}

If Emilie Snethlage's career were brought to the present day, it would not have major differences to other women working in the life sciences. Education and specialization at a university with some good teachers; an early career in a respected institution under the guidance of a renowned scientist; transference to a different country due to scientific and social contingencies; a professional career spanning several institutions; fieldwork and museum activities; publications of books and articles; administrative positions with increasing responsibilities; academic relationships with professionals and colleagues within the country and abroad. On the other hand, in order to establish a career as a female scientist in the first two decades of the twentiethcentury, a time when the struggle for women's rights intensified, Snethlage's trajectory had no other option but to be singular. A woman graduating at a time when universities were only just beginning to allow the entry of women; a professional in a world of science that was (and still is) dominated by men; a German in Brazil, a country at war with Germany; a foreigner without family within the society of Rio and Belém at the early twentiethcentury; a woman with long hair carrying a shotgun and shooting down birds among foresters, farmers, rubber tappers, and native Indians; a scientist particularly dedicated to fieldwork, but who could not stray away from hefty administrative responsibilities; a researcher between the traditions of nineteenthcentury naturalistic trips and the new scientific work that would define biology in the twentiethcentury.

During her career, Snethlage often sought to alleviate, circumvent, or overcome singularities, the socially imposed marks that could restrict her professional activities. The constant movement "between places," whether cultural, scientific, or social, which marked her career demanded the development and employment of specific strategies, whether consciously or unconsciously, through which she established her work's scientific legitimacy. I sought to present how negotiations occurred, strategies translated into practices, which enabled Snethlage to have her work accepted and approved in scientific circles and, more broadly, in the social environments where she exercised her activities.

The existing documentation does not indicate whether Emilie Snethlage engaged in feminist issues, as did her colleague Bertha Lutz. However, her activism could be perceived as the intense passion and extreme dedication devoted to her science and birds. The fact that many women may currently share a professional career similar to Snethlage's is one of the outcomes of such activism. 